\title{
Separation of phosphatase isoenzymes by gelfiltration
}

\author{
By \\ BENGT EstBorN \\ From the Central Laboratory, County Hospital of Boden, Siveden (Director: Dr. B. Estborn)
}

(Der Schriftleitung zugegangen am 20. Juli 1963)

Preliminary results of fractionation by gel filtration of alkaline and acid phosphatase from various sources are reported. The results indicate that the main alkaline phophatase activity of normal serum is derived from the liver. Acid phosphatases of prostatic and erythrocytic origin are distinctly separated by this method.

Es werden die vorläufigen Ergebnisse der Fraktionierung von alkalischer und saurer Phosphatases verschiedenen Ursprungs durch Gelfiltration mitgeteilt. Diese zeigen, daß sich die alkalische Phosphatase-Aktivität des normalen Serums in der Hauptsache von der Leber herleitet. Die sauren Phosphatasen der Prostata und der Erythrocyten werden mit dieser Methode scharf getrennt.

The demonstration of tissue specific isoenzymes of lactic dehydrogenase and their variations in certain diseases $(1,2,3)$ has invigorated the interest for further fractionation of other serum enzymes. Recently FLODIN and KILLANDER (4) have reported on the fractionation of human serum proteins by filtration through porous dextran gel "Sephadex G-200" (4). This method exposes the proteins to very mild conditions and the fractionation is independent of variations in $\mathrm{pH}$. The method therefore seemed especially suitable for separation of enzymes. - This report concerns preliminary results of fractionation by gelfiltration of alkaline and acid phosphatases obtained from various sources known to be rich in these enzymes.

\section{Experiments}

Tissue extracts of human liver, intestinal mucosa and bone were prepared according to Hodson et. al (5) with the exception that the final centrifugation was performed at $6000 \mathrm{~g}$ for 30 minutes. Bile, diluted 1:10 with saline before use, was procured by punture of a functioning gallbladder under operation. Leukocyte suspensions were prepared as described by Dioguardi et al. (6). The alkaline phosphatase was released from the cells by repeated freezing and thawing. Erythrocyte acid phosphatase was prepared from washed red blood cells haemolyzed by freezing and thawing. These extracts as well as a sample of seminal plasma containing prostatic acid phosphatase were centrifuged at $6000 \mathrm{~g}$ at $4^{\circ}$ and the supernatants used for the filtration experiments. Normal serum was obtained from healthy blood donors.

\section{Fractionation:}

Columns with bead polymerized dextran "Sephadex G-200" (Pharmacia, Uppsala, Sweden) were prepared as described by FLODIN (7). For the experiments on alkaline phosphatases a $4 \times 100 \mathrm{~cm}$ column equilibrated with a buffer consisting of $1 \mathrm{~m} \mathrm{NaCl}$ in $0.1 \mathrm{~m}$ Tris- $\mathrm{HCl}, \mathrm{pH}=8.0$, was used. The acid phosphatases were fractionated on a smaller column $2 \times 55 \mathrm{~cm}$ equilibrated with a $0.1 m$ citrate buffer, $\mathrm{pH}=5.5$, containing $1 \mathrm{~m} \mathrm{NaCl}$.

Samples of $2-12 \mathrm{~m} l$ were used for each experiment, the amount varying with the phosphatase activity of the extracts. To correlate the relative position of various peaks of activity $2-5 \mathrm{~m} /$ of normal serum was mixed with the extracts before the gelfiltration was started. The phosphatase of this serum had been inactivated by incubating at $57^{\circ}$ for one hour prior to use. The effluent from the large column was collected in $5 \mathrm{~m} /$ fractions, from the smaller one in $1 \mathrm{ml}$ fractions. The protein concentration was determined by ultraviolet absorbancy or according to DangHady et al. (8). The phosphatase activity at $\mathrm{pH}=10.5$ or 5.5 respectively was determined with p-nitrophenylphosphate ("Sigma 104") as substrate.

\section{Results}

The proteins of normal serum were separated by the gelfiltration in three main fractions (Fig. 1) as reported by FLodin and KILLANDER (4). When the alkaline phosphatase activity of the effluent was determined three peaks were obtained, the major one corresponding to the second protein fraction. The extract of intestinal mucosa revealed after gelfiltration two zones of activity coinciding with two of the peaks in normal serum. The main activity of the mucosal extract, however, was located in the region of the first protein fraction. It will be seen that the alkaline phosphatase obtained from leukocytes appeared as a single peak of activity in the same portion of the effluent.

Figure 2 shows that both the bile and the extracts of liver and bone contained alkaline phosphatases which

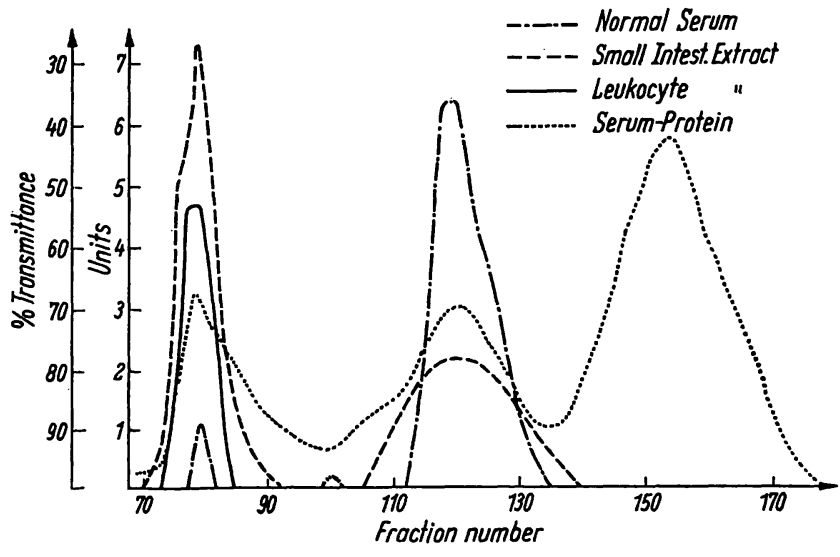

Fig. 1

Alkaline phosphatase activity after gelfiltration of normal serum and extracts of intestinal mucosa and leukocytes.

The enzyme activity is expressed in arbitrary units. For localization purpose fractionation pattern of normal scrum proteins is shown. 


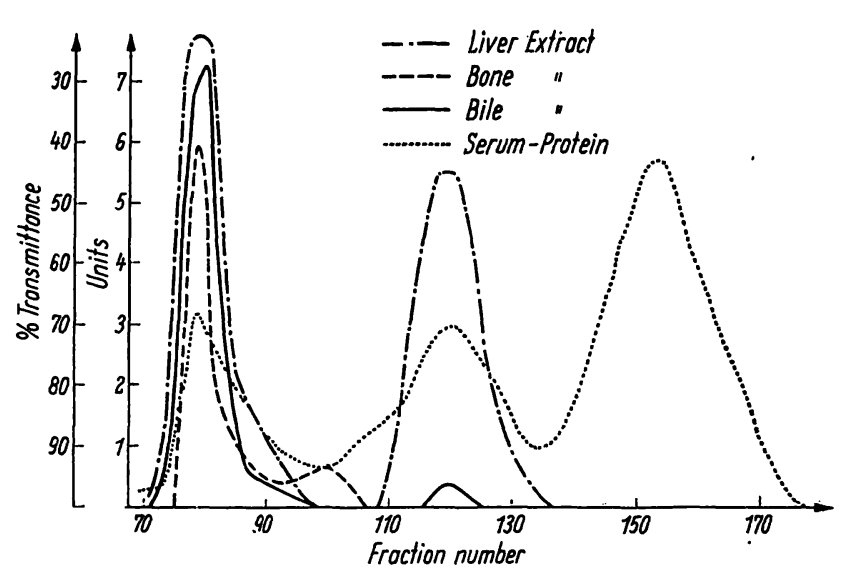

Fig. 2

Alkaline phosphatase activity after gelfiltration of bile and extracts of human liver and bone.

appeared in the effluent simultaneously with the first protein fraction. In addition the liver extract disclosed appreciable enzyme activity at the site of the second protein peak while the bile only contained minute phosphatase activity in this region. The experiment with bone extract also revealed a minor peak between the first two protein fractions.

Preliminary experiments were conducted to study the behavior in the gel of acid phosphatases of prostatic and erythrocytic origin. The acid phosphatase in seminal plasma was eluted as a single peak of activity in the region of the second protein fraction of normal serum (Fig. 3). The erythrocyte phosphatase activity on the other hand appeared in two well separated zones in the last part of the effluent.

\section{Discussion}

By filtration through dextran gel Sephadex G-200 it is possible to separate several different phosphatase isoenzymes. Similarly, isoenzymes of alkaline phosphatase have been demonstrated previously by electrophoresis in starch-gel $(5,9,10)$. The results of the experiments in the present series on alkaline phosphatase from various sources seem to indicate that the main activity of normal serum is derived from the liver and not from the bone system. It is interesting to note that the

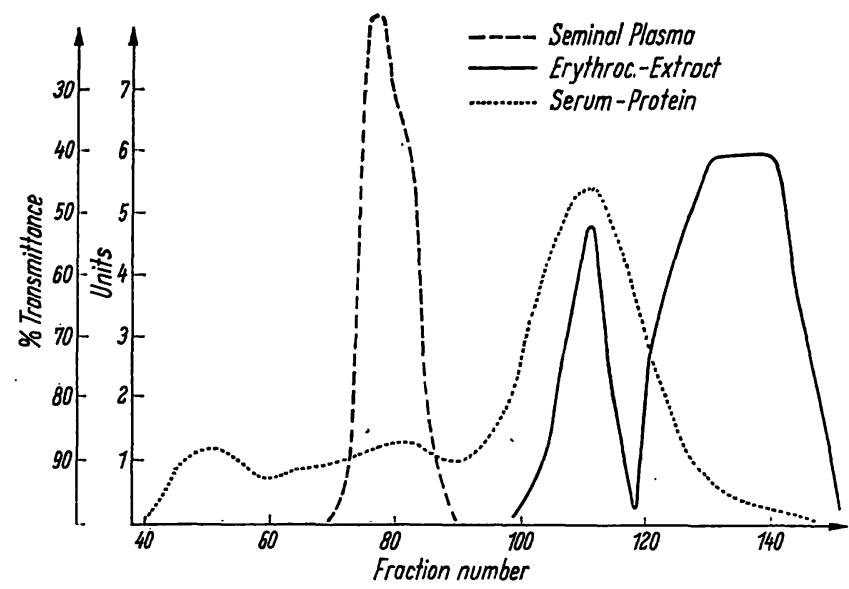

Fig. 3

Acid phosphatase activity after gelfiltration of seminal plasma and extract from erythrocytes.

alkaline phosphatase of bile behaves similarly in the gel as the bone phosphatase. This finding supports the generally accepted theory that the phosphatase of osseous origin is excreted through the bile (11). The results presented here imply that normally only small amounts of this enzyme enters the bloodstream. This is in agreement with the results recently reported by Hodson et al. (5). - The gel filtration-method may prove valuable in differentiating diseases with increased alkaline phosphatase activity in serum. Further experiments to evaluate the method in this respect are in progress.

The results on separation of acid phosphatase isoenzymes imply that the erythrocytes contain at least two acid phosphatases. The distinct separation of the prostatic and erythrocytic phosphatases indicate that there are differences in their molecular weights or structures. The gelfiltration method is readily applicable for use in a preparative scale. Experiments to further purify and characterize acid phosphatases from various sources have been undertaken.

\section{Acknowledgements:}

The stimulating interest of Dr. J. KrrLANDER, who introduced me into the technique of gelfiltration, is greatfully acknowledged. The author expresses appreciation to Miss M. WALLIN and Mrs. M. CarLsson for skilfull technical assistance.

\section{References}

1. Wieland, T. and G. Pfleiderer, Biochem. Z. 329, 112 (1957).2. Wieme, R. J., Clin. chim. Acta (Amsterdam) 4, 461 (1959). 3. Wroblewski, F. and K. F. Gregory, Ann. N. Y. Acad. Sc. 94, 912 (1961). - 4. Flodin, P. and J. KILLANDer, Biochim. biophysica Acta (Amsterdam) 63, 403 (1962). - 5. Hodson, A. W., A. L. Latner and L. Raine, Clin. chim. Acta (Amsterdam) 7, 255 (1962). - 6. Dioguardi, N., A. Agostoni, G. Fiorelli and B. Lomanto, J. Laborat. Clin. Med., S. Louis 61, 713 (1963). - 7.
Frodrn, $\cdot$ P., Dextran Gels and Their Applications in Gel Filtration, Thesis, University of Uppsala. AB Pharmacia, Uppsala (1962). 8. Danghady, W. H., O. H. Lowry, N. J. Rosebrough and W. S. FIELd, J. Laborat. Clin. Med., S. Louis 39, 663 (1952). - 9. Moss, D. W., Diana M. Campbell, Anagnostou-Kakaras and E. J. KING, Biochem. J. 81, 441 (1961). - 10. Moss, D. W. and E. J. King, Biochem. J. 82,19 P (1962). - 11. Gutman, A. B., Amer. J. Med. 27, 875 (1959).
Dr. Bengt Estborn County Hospital of Boden Boden, 19, Sweden. 